Supplement of Clim. Past, 13, 411-420, 2017

http://www.clim-past.net/13/411/2017/

doi:10.5194/cp-13-411-2017-supplement

(C) Author(s) 2017. CC Attribution 3.0 License.

(c) (i)

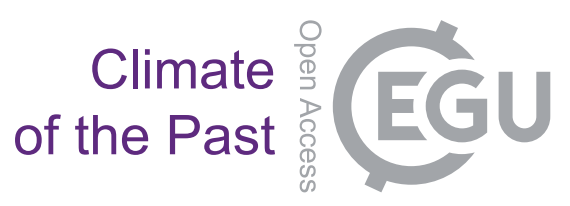

Supplement of

\title{
Influence of North Pacific decadal variability on the western Canadian Arctic over the past 700 years
}

François Lapointe et al.

Correspondence to: François Lapointe (francois.lapointe@ete.inrs.ca, frankvarve8@gmail.com)

The copyright of individual parts of the supplement might differ from the CC-BY 3.0 licence. 
2 Text 1

3 Period before $1300 \mathrm{CE}$

4 We note a weaker correlation between our record and the PDO-reconstruction (Macdonald

5 et al., 2005) prior to $\sim 1300 \mathrm{CE}$ during a period that corresponds broadly with a thick

6 erosive layer dated $\sim 1300 \mathrm{CE}$ in the varve chronology (Lapointe et al., 2012) (Fig. S6).

7 This layer has been suggested to be the consequence of a mass movement deposit in a

8 recent study (Normandeau et al., 2016a). However, this event is also relatively

9 synchronous with an unprecedented negative anomaly in the reconstructed PDO occurring

10 around 1296 CE (Macdonald et al., 2005). Cross-correlation between these two proxy

11 records shows a significant correlation between 993-1299 CE when VT is shifted by 45

12 years (CBEL lags PDO by 45 years, $r=-0.20, p<0.001$; Fig. S7), suggesting that the large

13 debris flow at $\sim 1300$ CE likely eroded 45 varves. It is worth noting that the tree-ring based

14 PDO reconstruction values prior to $1300 \mathrm{CE}$ are almost constantly negative. Moreover, the

15 period encompassing 1000-1300 CE is characterized by periods of massive droughts in the

16 southwestern USA, causing a deficit of soil-water recharge and possibly widespread tree

17 mortality in this region (Williams et al., 2013). In any case, the low distribution of tree-

18 rings prior to $1300 \mathrm{CE}$ impedes a good understanding of the climate in the Northern

19 latitudes (Wilson et al., 2015). 

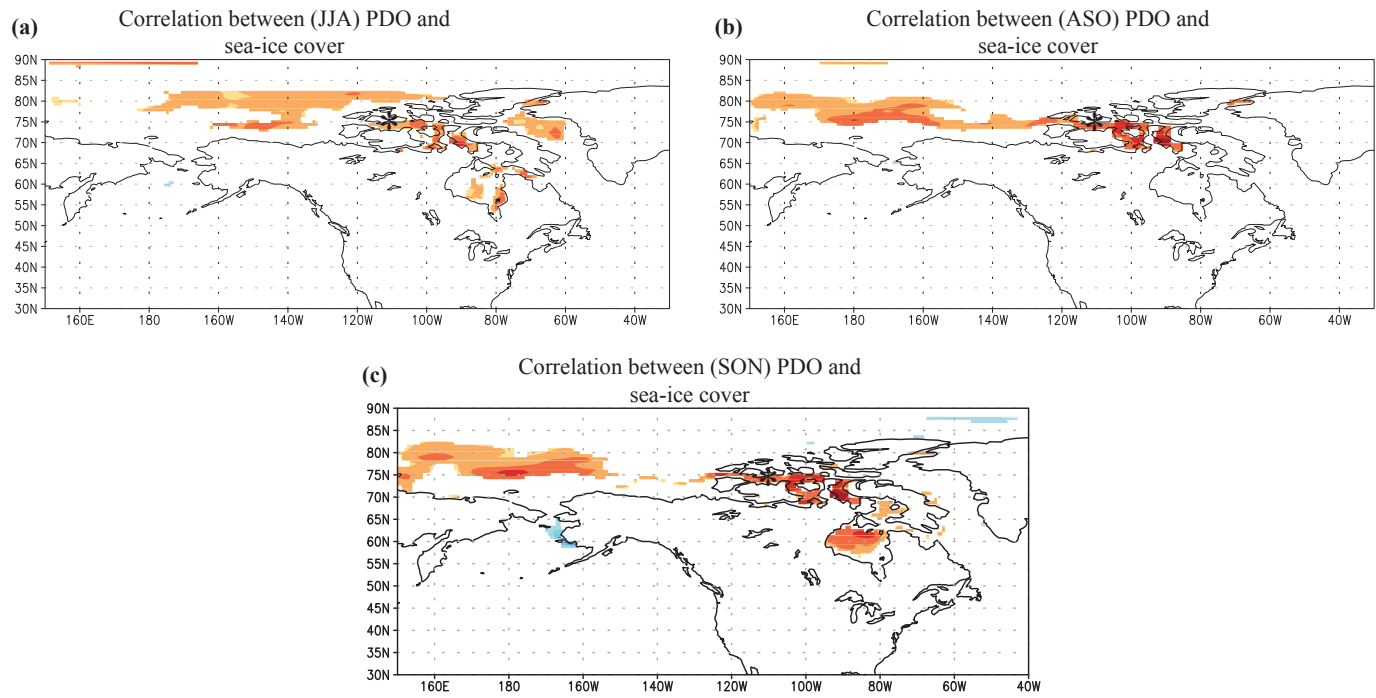

Figure S1. Sea-ice cover anomalies in relation to PDO phases during summer and autumn. Correlation between PDO (Huang et al., 2015) and sea-ice anomalies from ERA-Interim (Dee et al., 2011) for June-August (a), August-October (b), and September-November (c) during 1979-2016. Black asterisk denotes Cape Bounty.

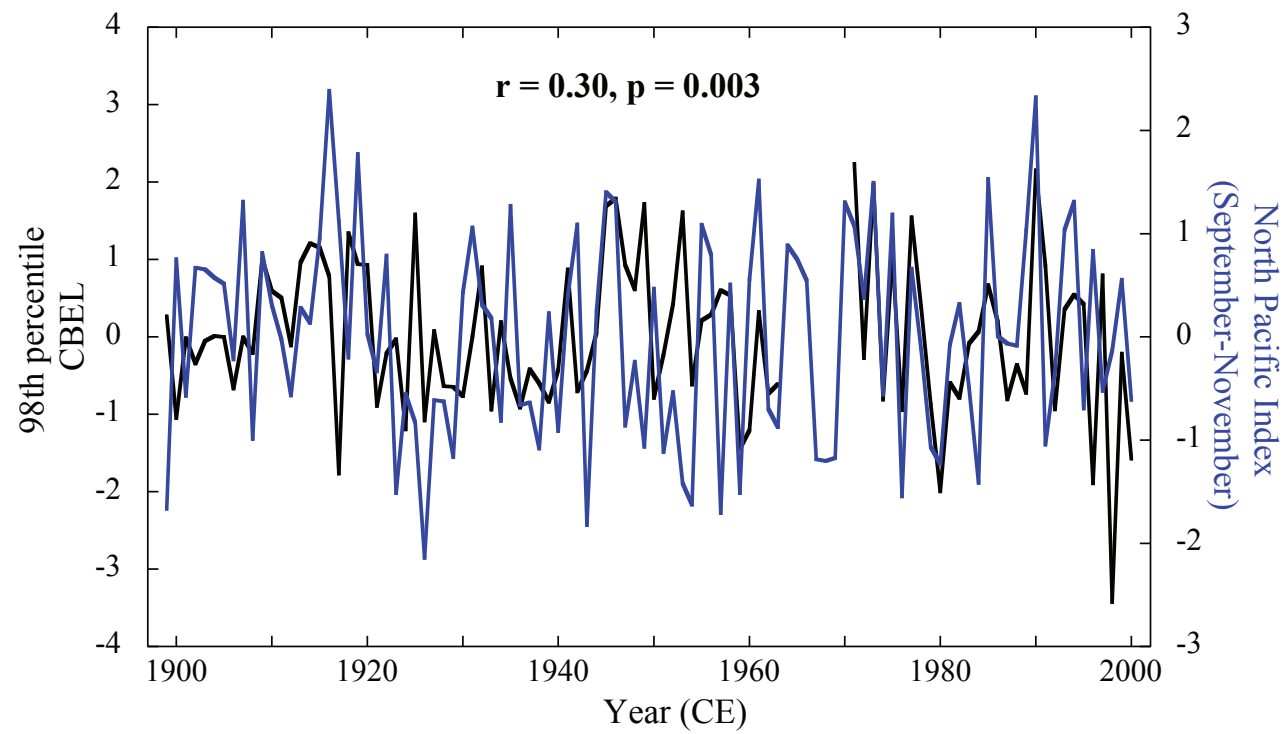

Figure S2. Correlation between the $98^{\text {th }}$ percentile at CBEL (Lapointe et al. 2012) 28 and the NPI during September-November (Trenberth and Hurrell 1994) for the past 29100 years. 


\section{PC1 of PDOs versus CBEL VT}

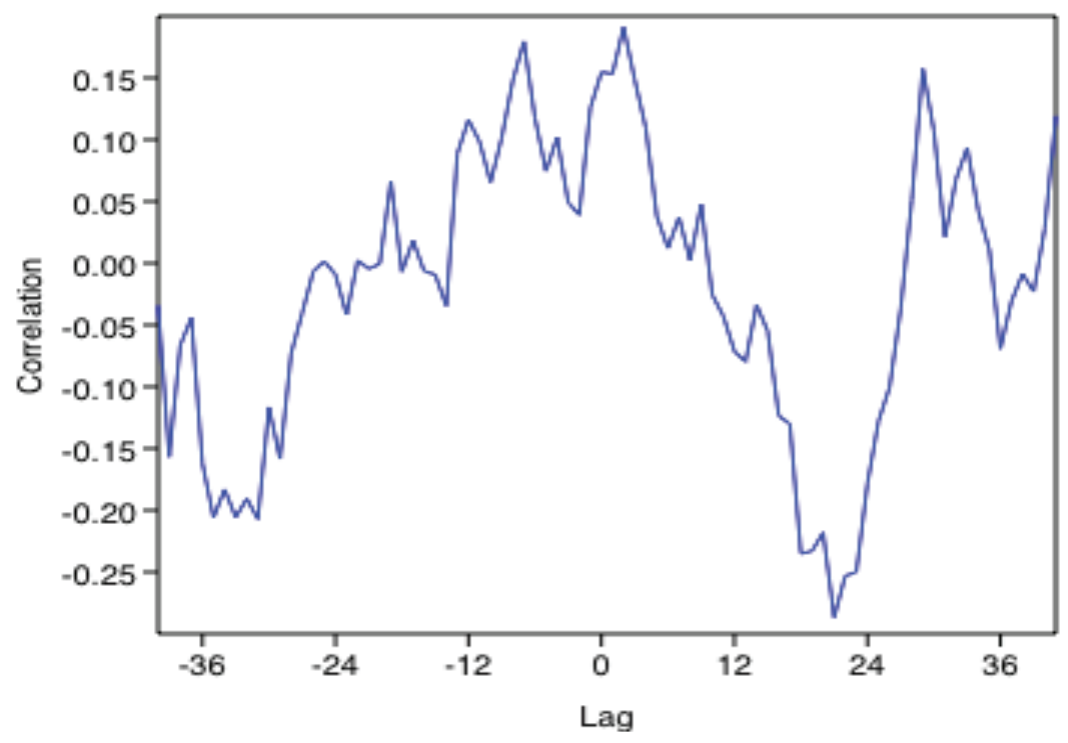

32 Figure S3. Cross-correlation between annual PC1 of reconstructed PDOs 33 (MacDonald and Case 2005, D'Arrigo et al. 2001, Gedalof and Smith 2001) versus 34 annual CBEL varve thickness from 1700-1900. Maximum correlation is reached at 18 year lag, that is CBEL leads the PDO reconstructions.

Figure S4. Large turbidite showing erosive features. The black lines indicate the thickness of the layer $(1.34 \mathrm{~cm})$ dated to $1446 \mathrm{CE}$. The backscattered electron

41 image acquired at the scanning electron microscope shows the base of the turbidite

42 (red square). Core \# CBEV1, depth from top: $101.88 \mathrm{~cm}$. 
44

45

46

47

48

49

50

51

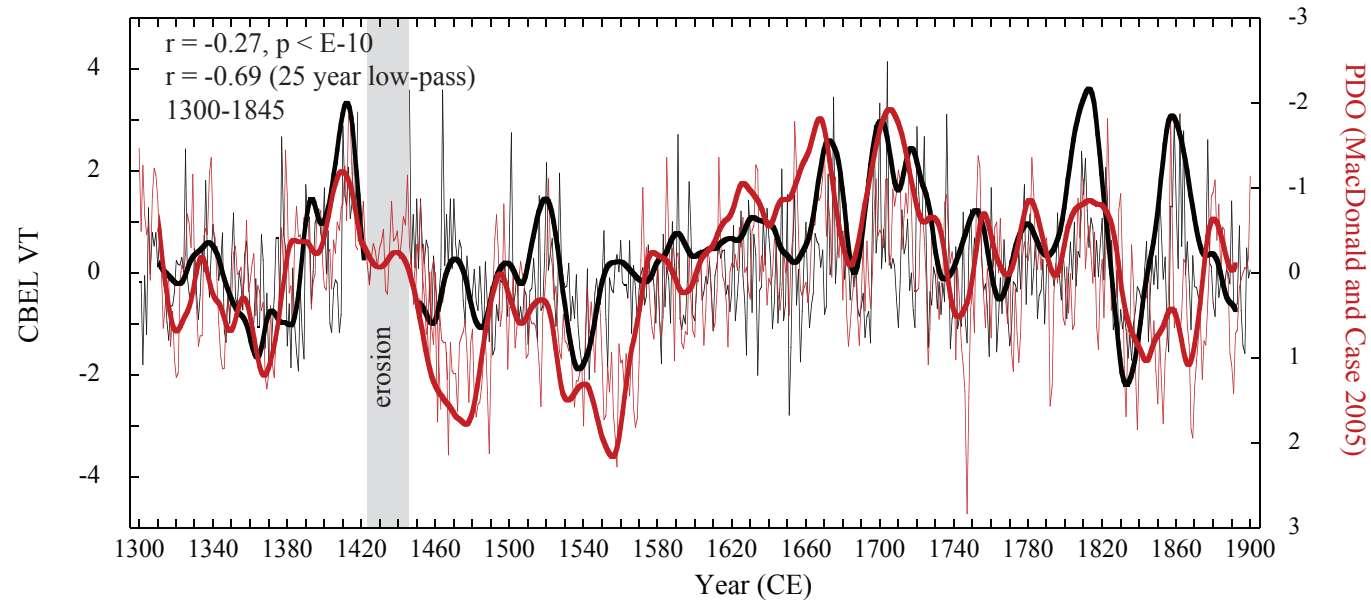

Figure S5. Comparison between CBEL varve thickness and the Pacific Decadal Oscillation (Macdonald et al., 2005) over the last $\sim 700$ years. Bold lines are 25-year low-pass filter. Grey shading (b) indicates the 28 years eroded varves at CBEL.

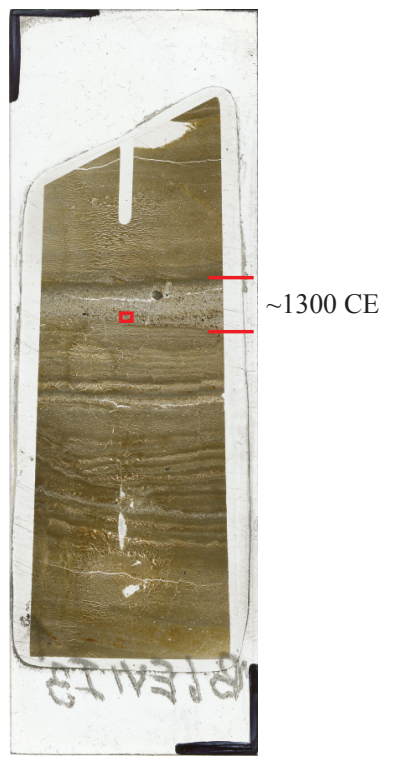

Base of the layer

showing erosive

feature (red square)

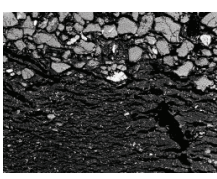

$10 \bar{\mu} \mathrm{m}$

53 Figure S6. Largest debris flow deposit dated to $\sim 1300 \mathrm{CE}$. The backscattered 54 electron image acquired at the scanning electron microscope shows the base of the 55 debris flow (red square). Core \# CBEV1, depth from top: $130.14 \mathrm{~cm}$.

56

57

58

59

60 


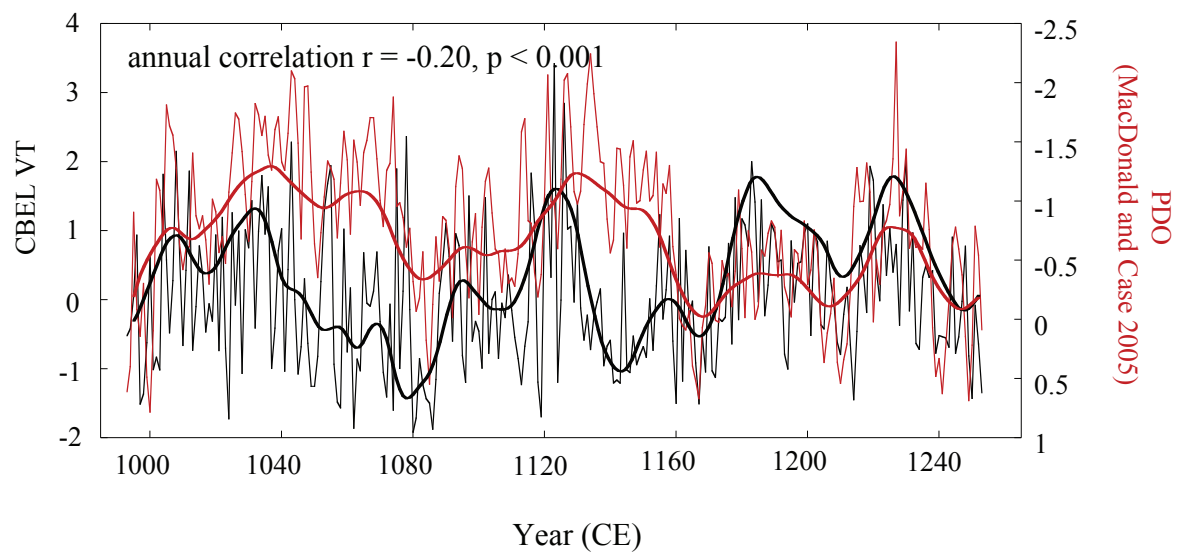

61

62 Figure S7. Varve thickness versus reconstructed PDO(Macdonald et al., 2005) 63 during the Medieval Climate Anomaly. Bold lines are 25-year low-pass filter.

64 Varve thickness is shifted 45 years earlier.

65

(a) PDO from Gedalof and Smith versus CBEL

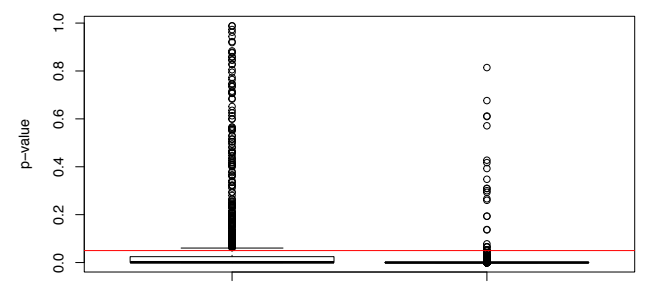

(c) PDO from D'Arrigo et al. versus CBEL

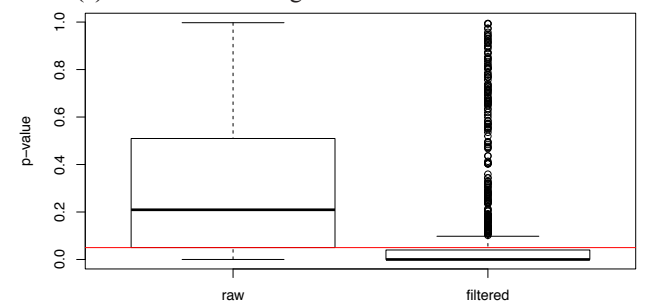

(b) PDO from MacDonald and Case versus CBEL

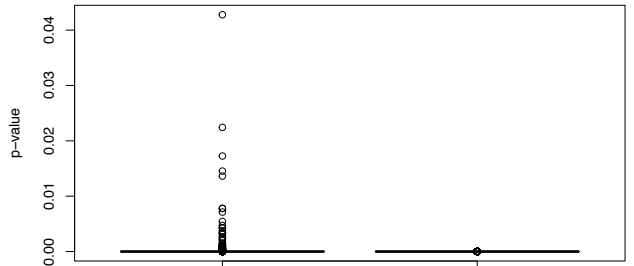

(d) PC1 of the PDOs versus CBEL

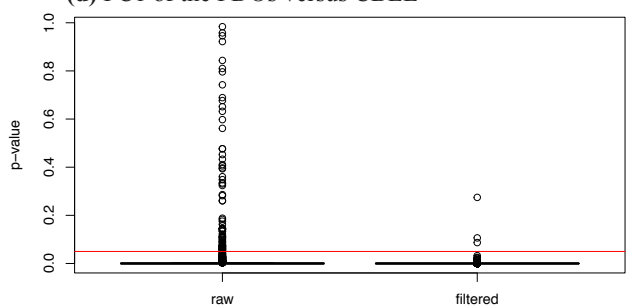

66

67

68

69

70

71

Figure S8. $p$-values for the correlations between (raw and filtered) reconstructed PDOs and CBEL VT using a nonparametric stationary bootstrap (1000 iterations). Red line is the $95 \%$ confidence levels. 

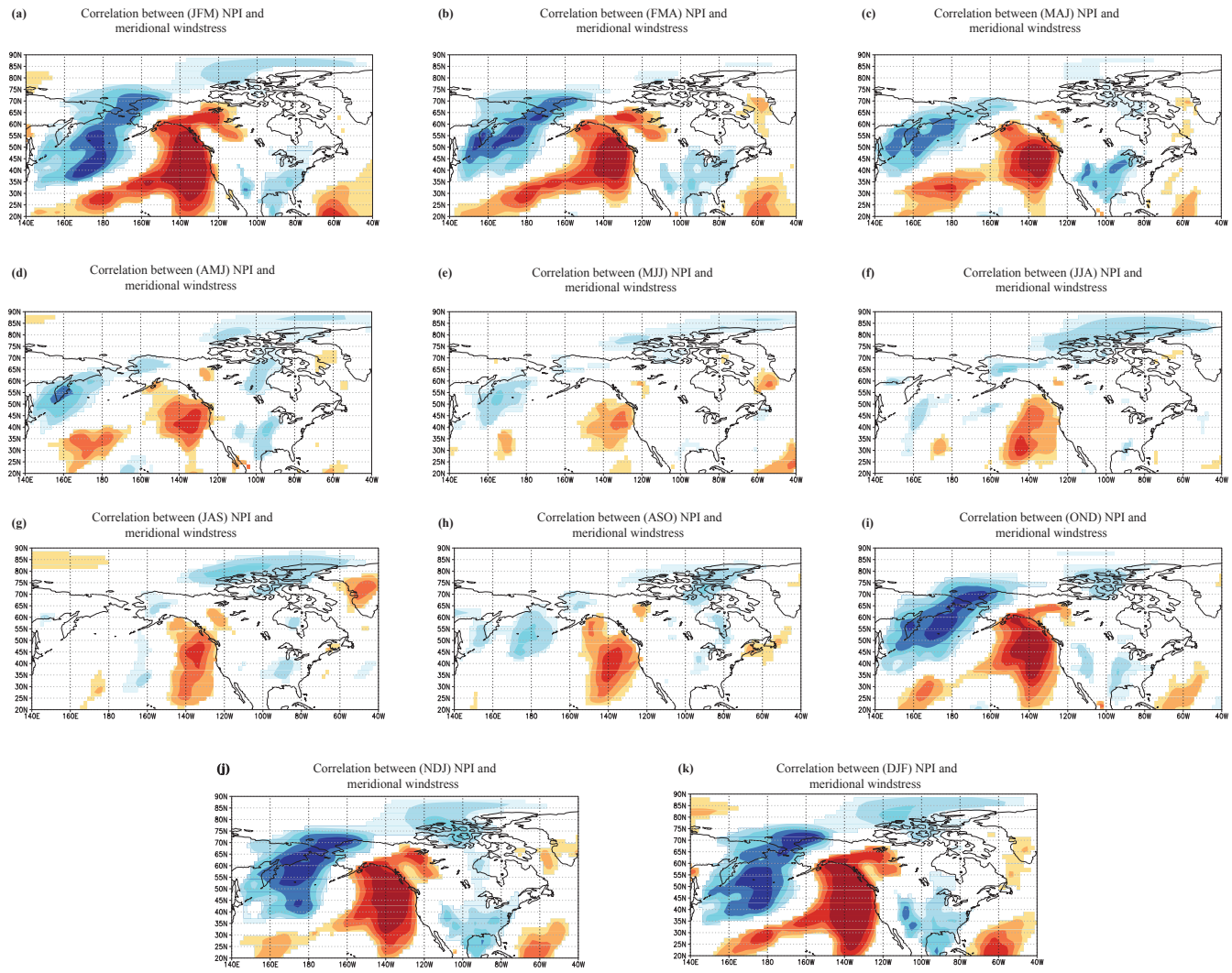

Figure S9. Same as Figure 6a, but for all year-round except SON (as it is in the main text). (a) averaged January-March, (b) February-April, (c) March-May, (d) April-June, (e) May-July, (f) June-August, (g) July-September, (h) August-October, 
Correlation between PDO and

(a) surface temperature during JAS

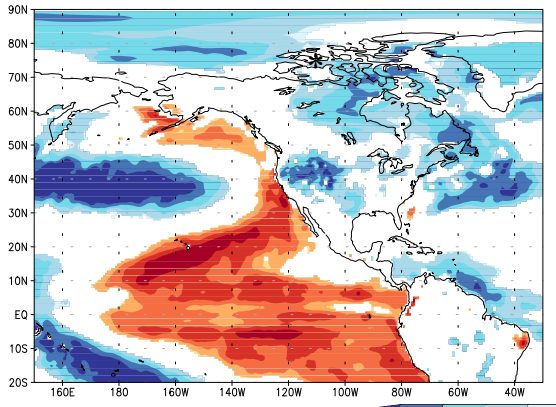

Correlation between NPI and

(b) surface temperature during JAS

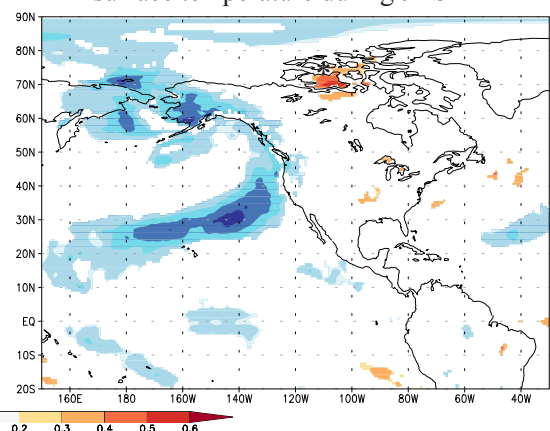

Figure S10. North Pacific influences on temperature anomalies in the western

95

Figure S11. Summer sea ice extent covering $84^{\circ}-67^{\circ} \mathrm{N} / 100^{\circ} \mathrm{W}-170^{\circ} \mathrm{E}$ compared to the $98^{\text {th }}$ percentile at CBEL.

Canadian Arctic. (a), Spatial correlation between July-September PDO index and July-September surface temperature (Dee et al., 2011) for 1979-2016. (b), as in (a), but for the North Pacific Index (Trenberth et al., 1994).

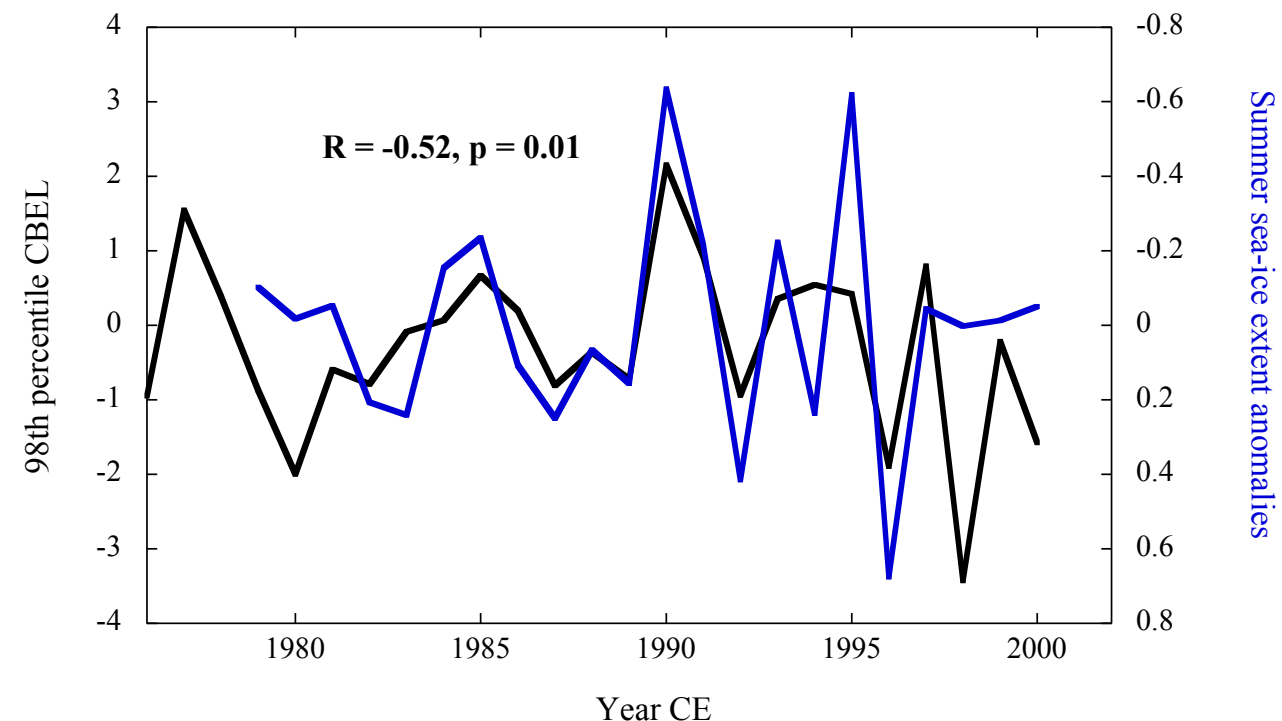


111

112

113

114

115

116

117

118

119

120

121

122

123

124

125

126

127

128

129

130

131

132

133

134

135

136

137

138

139

140

141

142

143

144

145

146

147

148

149

150

151

152

153

\section{References}

Cuven, S., Francus, P. and Lamoureux SF.: Mid to Late Holocene hydroclimatic and geochemical records from the varved sediments of East Lake, Cape Bounty, Canadian High Arctic, Quatern. Sci. Rev., 30 2651-2665, 2011.

Dee, D., S. Uppala, A., Simmons, P., Berrisford, P., Poli, S., Kobayashi, U., Andrae, M., Balmaseda, G., Balsamo and Bauer P.: The ERA-Interim reanalysis: Configuration and performance of the data assimilation system, Q. J. R. Meteorol. Soc., 137, 553-597, 10.1002/qj.828, 2011.

Huang, B., Banzon, V. F., Freeman, E., Lawrimore, J., Liu, W., Peterson, T.C., Smith, T.M., Thorne, P.W., Woodruff, S.D. and Zhang, H.-M.: Extended reconstructed sea surface temperature version 4 (ERSST. v4), Part I: upgrades and intercomparisons, J. Climate, 28, 911-930, 2015.

Lapointe, F., Francus, P., Lamoureux, SF., Saïd, M. and Cuven, S.: 1750 years of large rainfall events inferred from particle size at East Lake, Cape Bounty, Melville Island, Canada, J. Paleolimnol., 48, 159-173, doi: 10.1007/s10933-012-9611-8, 2012.

MacDonald, G. M. and Case, R.A.: Variations in the Pacific Decadal Oscillation over the past millennium, Geophys. Res. Lett., 32, 10.1029/2005GL022478, 2005.

Normandeau A., Joyal G., Lajeunesse P., Francus P., Lamoureux SF. and Lapointe F.: Late-Holocene Mass Movements in High Arctic East Lake, Melville Island (Western Canadian Arctic Archipelago). Submarine Mass Movements and their Consequences: Springer; 2016. p. 311-20.

Normandeau, A., Lamoureux, SF., Lajeunesse, P. and P. Francus.:, Sediment dynamics in paired High Arctic lakes revealed from high-resolution swath bathymetry and acoustic stratigraphy surveys, J. Geophys. Res.: Earth Surface., 2016b.

Ojala, A., Francus, P., Zolitschka, B., Besonen M., and Lamoureux, SF.: Characteristics of sedimentary varve chronologies-a review, Quatern. Sci. Rev., 43, 45-60, 2012.

Trenberth, K. E. and Hurrell, J.W.: Decadal atmosphere-ocean variations in the Pacific. Clim. Dynam.,9, 303-319, doi:10.1007/BF00204745, 1994.

Williams, A. P., Allen, C.D., Macalady, AK., Griffin, D., Woodhouse, C.A., Meko, D.M., $\quad$ Swetnam, T.W., Rauscher, S.A., Seager, R. and Grissino-Mayer, H.D.: Temperature as a potent driver of regional forest drought stress and tree mortality, Nature Clim. Change, 3(3), 292-297, 2013.

Wilson, R., K. Anchukaitis, K. Briffa, U. Büntgen, E. Cook, R. D'Arrigo, J. Esper, D. Frank, B. Gunnarson, and G. Hegerl (2015), Are tree-ring based estimates for Northern Hemisphere medieval temperatures fit for purpose?, paper presented at EGU General Assembly Conference Abstracts. 